\title{
PEMBERDAYAAN PENDIDIK \\ (STUDI KASUS PENGEMBANGAN KEPROFESIAN BERKELANJUTAN GURU DI SMK N SENI)
}

\author{
Anggita Laras Pratama \\ SMPN 2 Mandiraja Banjarnegara \\ gitalaras44@gmail.com
}

\begin{abstract}
Abstrak
Penelitian ini bertujuan untuk mendeskripsikan: (1) pemberdayaan pendidik khususnya PKB SMK Negeri Seni di Kabupaten Bantul; (2) hambatan, dan (3) solusi pemberdayaan pendidik khususnya PKB SMK Negeri Seni di Kabupaten Bantul. Penelitian ini merupakan studi kasus dengan pendekatan kualitatif. Subjek penelitian adalah kepala sekolah dan guru SMK Negeri Seni. Data penelitian dikumpulkan melalui pengamatan langsung (observasi), analisis dokumen, dan wawancara secara mendalam. Hasil penelitian ini adalah sebagai berikut. (1) Kondisi profesionalisme guru di SMK Negeri Seni ditunjukan dengan kualifikasi akademik guru yang sebagian besar sudah sesuai dan memenuhi kriteria guru profesional; (2) program pemberdayaan pendidik dilakukan dengan cara terus mengembangkan guru; (3) pelaksanaan program PKB guru SMK Seni di Kabupaten Bantul meliputi kegiatan perencanaan, pelaksanaan, dan evaluasi; (a) kegiatan PKB yang berkaitan dengan pengembangan diri dilakukan dengan cara mengikuti seminar, workshop, membuat rancangan pembelajaran seperti RPP, dan modul; (b) bebeapa guru sudah menjalankan kegiatan publikasi ilmiah; (c) kegiatan karya inovatif lebih banyak dilaksanakan; (4) manfaat dari PKB yaitu guru dapat memenuhi standar dan mengembangkan kompetensinya; (5) hambatan dalam pelaksanaan PKB yaitu masalah waktu, kurangnya rasa percaya diri, beban pekerjaan yang tinggi; (6) guru lebih banyak melakukan kegiatan PKB yang berkaitan dengan karya inovatif; (7) upaya untuk mengatasi hambatan dari segi waktu, guru dituntut untuk mampu memanajemen waktu dengan baik.
\end{abstract}

Kata kunci: pemberdayaan pendidik, profesionalisme dan pengembangan keprofesian berkelanjutan, Guru

\section{EMPOWERMENT OF TEACHERS (A CASE STUDY OF TEACHER CONTINUOUS PROFESSIONAL DEVELOPMENT AT SMK N OF ART)}

\author{
Anggita Laras Pratama \\ SMPN 2 Mandiraja Banjarnegara \\ gitalaras44@gmail.com
}

\begin{abstract}
This research aims to describe: (1) the empowerment of teachers in vacational CPD of art in Bantul, and (2) the obsacles and (3) the efforts to overcome obsacles for the empowerment of teachers in vacational CPD of art in Bantul District. This research was a case study with the qualitative approach. The research subjects comprised vice principals and teachers of SMK $N$ of art. The data were collected through observations, document analysis, and in-depth interviews. The results of this research are as follows. (1) The teachers professionalism condition in SMK N of art shown the academic suitability qualification of teachers and has been fullfilled by criteria of the teacher professionalism; (2) empowerment of teachers program is done by always developing teachers; (3) the CPD program of art vacational school teachers in Bantul District includes planning, implementation and evaluation activities; (a) the activities are conducted by attending seminars, workshops, drafting of learning such as lesson plans, and module; (b) some teachers have done the program of scientific publications; (c) innovative work activities were by implemented more teachers; (4) the benefits of the CPD are that teachers are able to meet the standard and develop their competencies; (5) the obstacles in the implementation of CPD are related to time, lack of confidence, high load of working; (6) teachers do more innovative work in CPD program; (7) the efforts to overcome the obstacles in terms of time is by requiring teachers to be able to manage the time well.
\end{abstract}

Keywords: teacher empowerment, professionalism and continuous professional development 


\section{Pendahuluan}

Persoalan mutu pendidikan merupakan isu yang selalu hangat dan manarik untuk diperbincangkan dan dikaji. Persoalan mutu pendidikan ini selaras dengan tuntutan perkembangan dan perubahan zaman. Mutu pendidikan akan tercapai apabila komponen dalam manajemennya dapat berjalan dengan baik. Guru atau tenaga pendidik merupakan salah satu faktor penentu tercapainya mutu pendidikan. Pendidik dan tenaga kependidikan merupakan salah satu dari Standar Nasional Pendidikan yang memerlukan perhatian khusus dari pemerintah dan masyarakat. Pendidik dan tenaga kependidikan dalam proses pendidikan memegang peran strategis terutama membentuk watak bangsa melalui pengembangan kepribadian dan nilai-nilai yang diinginkan.

Pada dasarnya setiap satuan pendidikan menerapkan sistem manejemen, baik di kota maupun di desa, baik di tingkat dasar maupun menengah, baik negeri maupun swasta. Akan tetapi, kegiatan dari manajemen pendidik dan tenaga kependidikan tidak senua berjalan dengan ideal. Misalnya, wujud dari pemberdayaan pendidik dan tenaga kependidikan sering kali diabaikan. Hal ini mengakibatkan kurang adanya perbaikan bahkan peningkatan dalam kompetensi pendidik sebagai guru profesional. Padahal kegiatan ini memiliki peranan yang sangat menentukan untuk pengembangan keprofesionalan guru secara berkelanjutan. Selain itu, kegiataan pemberdayaan ini sebagai bentuk tindak lanjut pemerintah terhadap kebijakan pendidikan tentang adanya program sertifikasi guru. Seperti diketahui program ini memberikan kesempatan bagi pendidik untuk termotivasi dalam meningkatkan kompetensinya dengan menambah jumlah tunjangan gaji setiap bulannya. Dengan adanya peningkatan kesejahteraan ini, maka seharusnya guru mampu lebih berkonsentrasi lagi dalam mengembangkan dan meningkatkan kompetensinya.

Permasalahan yang terkait dengan kurang adanya perhatian guru terhadap pembinaan dan pengembangan profesio- nalisme yang sering dihadapi oleh satuan pendidikan di daerah manapun terutama di Daerah Istimewa Yogyakarta. Provinsi ini merupakan kota pelajar yang memiliki puluhan lembaga pendidikan yang berkualitas. Hal ini dapat dilihat dari jumlah peserta didik dari daerah lain yang menempuh pendidikan di Daerah Istemewa Yogyakarta dari tahun ke tahun. Semakin banyak lembaga pendidikan, tentu akan semakin banyak variasi permasalahan yang dihadapi. Salah satunya terkait dengan pemberdayaan guru.

Pemberdayaan guru yang baik akan mempengaruhi kinerja guru dalam melaksanakan tugas dan tanggung jawabnya. Kinerja guru dipandang sangat berpengaruh terhadap peningkatan kualitas pendidikan. Maka dari itu untuk menjaga profesionalitas guru yaitu melalui penilaian kinerja guru, penilaian ini diperlukan sebagai persyaratan peningkatan dan pembinaan karier kepangkatan dan jabatan guru. Penilaian kinerja guru dilaksanakan melalui penilaian angka kredit, yang meliputi unsur: pendidikan, pembelajaran/bimbingan dan tugas tertentu, pengembangan keprofesian berkelanjutan dan penunjang tugas guru. Jika selama ini unsur pendidikan, pembelajaran/bimbingan dan tugas tertentu sudah menjadi kegiatan rutin tugas gu$\mathrm{ru}$, sehinggga tidak menjadi permasalahan rumit bagi guru untuk melaksanakan dan mengumpulkan angka kreditnya, tidak demikian halnya dengan pengembangan profesi guru yang selama ini belum menjadi perhatian dan belum menjadi bagian penting dari kegiatan guru dalam mempertahankan profesionalitasnya.

Kasus ini telah teridentifikasi di salah satu daerah di Daerah Istemewa Yogyakarta, yaitu Kabupaten Bantul. Di kota ini terdapat 3 Sekolah Menengah Kejuruan (SMK) Negeri Seni yang menjadi fokus penelitian. Alasan memilih sekolah ini, karena penelitian ini mengidentifikasi berbagai permasalahan terkait dengan manajemen pendidik dan tenaga kependidikan, khususnya tentang pemberdayaan, pembinaan atau pengembangan keprofesian berkelanjutan yang ada di sekolah ini. 
Alasan lain karena karakteristik guru kejuruan seni yang banyak terdiri dari guru mata pelajaran produktif lebih sering membuat penciptaan karya seni daripada melaksanakan kegiatan yang berhubungan dengan tulis menulis.

Berdasarkan studi awal berupa observasi di lapangan dan wawancara terhadap beberapa guru SMK Negeri Seni Kabupaten Bantul, menunjukkan bahwa selama ini, pengembangan keprofesian guru SMK masih bersifat parsial, belum menunjukkan keberlanjutan, dan belum terlaksana secara optimal. Hal ini ditunjukkan antara lain: (1) kurangnya pemahaman guru seni terhadap program pengembangan keprofesian berkelanjutan guru; (2) masih cukup banyak guru SMK yang enggan mengikuti kegiatan PKB terutama dalam hal publikasi ilmiah yang erat kaitannya dengan tulismenulis; (3) masih cukup banyak guru SMK yang cenderung mengabaikan kegiatan PKB karena kurangnya motivasi dan adanya kebingungan guru, sehingga banyak guru yang kurang berminat melaksanakan kegiatan PKB.

Permeneg PAN dan RB No. 16 Tahun 2009 per Tanggal 1 Januari 2013 mengenai pengembangan keprofesian berkelanjutan, merupakan suatu hal yang baik sebagai sarana untuk mewujudkan profesionalisme guru atau pendidik di Indonesia. Meskipun kegiatan PKB telah dilaksanakan namun para guru SMK N Seni jarang mengikutinya, hal ini menyebabkan sosialisasi Permeneg PAN dan RB belum cukup efektif untuk menyadarkan para guru memahami pentingnya PKB dan mewujudkannya dalam bentuk faktual. Oleh karena itu sosialisasi dan pelatihan secara berkesinambungan sangat diperlukan agar kegiatan PKB dapat menjadi kegiatan rutin dan mandiri bagi para guru secara individu maupun kelompok.

Pernyataan yang ditulis salah satu guru SMK Negeri 2 Kasihan, Bantul dalam buletin Bina Prestasi edisi kedua tahun 2014 (Suprijadi, 2014), beliau menyatakan bahwa:

Kegiatan PKB adalah salah satu regulasi pemerintah yang sangat ideal, rumit, detail, kompleks dan jika itu diterapkan pada guru, maka akan melahirkan pendidik yang hebat, tangguh dan profesional. Waktu yang sempit, yakni setelah guru menyusun perangkat proses belajar mengajar (PBM) meliputi silabus, program semester, program tahunan, minggu efektif, RPP, pelaksanaan PBM, evaluasi atau test; remidial dan pengayaan; analisis soal dan tugas-tugas tambahan lainnya, guru masih dituntut melaksanaan PKB (pengembangan diri, publikasi ilmiah, karya inovatif). Masih ditambah lagi dengan tuntutan beban mengajar atau tatap muka minimal 24 jam dan maksimal 40 jam perminggu, itu semua sungguh merupakan beban yang amat berat bagi guru saat ini.

Hal ini menunjukan bahwa program PKB dirasakan oleh guru SMK N Seni sebagai hal yang berat untuk dilaksanakan karena berbagai kendala. Dengan beban tugas guru yang berkenaan dengan kegiatan administratifnya serta jam mengajar yang sudah banyak, menjadikan sebagian guru cenderung malas untuk melaksanakan kegiatan PKB. Peraturan yang mengharuskan guru untuk melaksanakan kegiatan PKB secara keseluruhan baik itu pengembangan diri, publikasi ilmiah dan karya inovatif yang nantinya dapat digunakan untuk kenaikan angka kredit membuat guru semakin kebingungan dengan program kegiatan ini.

Penelitian ini dilakukan untuk mendeskripsikan bagaimana guru di SMK N Seni dalam melaksanakan dan menjalani kegiatan pengembangan keprofesian berkelanjutan. Mengingat para guru seni yang berada di ketiga sekolah ini cenderung mengabaikan kegiatan ini, meski kegiatan ini telah terencana di dalam SMK Negeri Seni tersebut. Oleh karena itu penelitian ini penting dilakukan untuk mengungkap "Pemberdayaan pendidik di SMK Negeri Seni di Kabupaten Bantul (Studi kasus pengembangan keprofesian berkelanjutan guru di sekolah menengah kejuruan di kabupaten Bantul)“.

Northouse (2013, p. 12) menyatakan bahwa manajemen diciptakan untuk mengurangi kekacauan di dalam organisasi 
dan untuk mengelola organisasi agar lebih efektif dan efisien "management was created as a way to reduce chaos in organizations and to make them run more effectively and efficiently. Selanjutnya, menurut Terry (Usman, 2013, p. 58) menyebutkan bahwa "fungsifungsi manajemen meliputi perencanaan (planning), pengorganisasian (organizing), pelaksanaan (actuating) dan pengawasan (controlling)". Mengacu pada fungsi-fungsi manajemen tersebut, maka pemberdayaan pendidik di sekolah dapat dibentuk secara efektif. Kauffman (Engkoswara \& Komariah, 2010, p. 49) menyatakan bahwa perencanaan adalah proses penentuan tujuan atau sasaran yang hendak dicapai dan menetapkan jalan dan sumber yang diperlukan untuk mencapai tujuan itu seefisien dan sefektif mungkin. Perencanaan akan meningkatkan efisiensi organisasi dan efektivitasnya. Ghayyur (Wibowo, 2013, p. 55) memberikan batasan tentang pengorganisasian sebagai berikut: "it involves the process of determining what tasks are to be done. Who is to do them? How the tasks are to be grouped? Who reports to whom and where decisions are to be made". Pengorganisasian merupakan sutu proses penentuan tugastugas yang harus dilakukan, bagaimana tugas-tugas tersebut dikelompokkan dan siapa yang harus melapor tentang keputusan yang telah dibuat. Pelaksanaan berkaitan erat dengan kegiatan pemimpin atau manajer dalam memberikan pengarahan sumber daya yang ada dalam organisasi. Pengarahan berarti menggerakkan sumber daya yang ada, khususnya sumber daya manusia (SDM) untuk melaksanakan pekerjaan secara bersama-sama sesuai dengan yang telah direncanakan organisasi.

Mockler (Engkoswara \& Komariah, 2010, p. 219) memberikan definisi tentang pengawasan sebagai berikut:

Suatu usaha sistematis untuk menetapkan standar pelaksanaan dengan tujuan-tujuan perencanaan, merancang sistem informasi umpan balik, membandingkan kegiatan nyata dengan standar yang telah ditetapkan sebelumnya, menentukan dan mengukur penyimpangan-penyimpangan, serta mengambil tindakan koreksi yang diperlukan untuk menjamin bahwa semua sumber daya perusahaan digunakan dengan cara paling efektif dan efisien dalam tujuan-tujuan organisasi.

Manajemen pendidikan dalam arti khusus (administratif) berlaku dalam konteks organisasi/lembaga pendidikan sebagai satu kesatuan, dan berkenaan dengan tugas pokok (fungsi) administrator/manajer (pimpinan) lembaga tersebut yang harus membuat program kerja kelembagaan. Jadi, kunci pokoknya pada pembuatan dan pelaksanaan program kerja lembaga/ organisasi. (Tim Dosen Administrasi Pendidikan Universitas Pendidikan Indonesia, 2013, pp. 10-12).

Mahapatro (2010, pp. 252-254) berpendapat bahwa :

Of all the resources, the 'human resources' is the most significant and the only active factor of production. All other factors like capital, materials, buildings, plant and machinery, etc. Remain inactive unless there are competent people to utilize them for producing goods and services desired bythe society. The goal of achieving the greater quality and higher productivity depends on the skills of people.

Berarti bahwa dari semua sumber daya yang ada, sumber daya manusia adalah sumber daya yang paling penting dan merupakan faktor aktif dalam proses produksi. Seluruh faktor yang lain seperti uang, alat-alat, bangunan, tanaman, dan mesin, dan lain lain tidak akan bermanfaat jika tidak terdapat orang-orang kompeten yang menggunakannya dalam menghasilkan barang dan pelayanan yang diinginkan oleh masyarakat. Tujuan dalam mencapai kualitas yang lebih baik dan menghasilkan produktivitas yang lebih tinggi tergantung pada keterampilan yang dimiliki oleh anggota organisasi.

Peningkatan prestasi atau hasil karya tidak akan terlepas dari pemberdayaan semua pihak yang terlibat. "Empowerment is defined as a group's or individual's capacity to make effective choices, that is, to make choices and then to transform those choices into desired actions and outcomes" (Aslop, Bertelson, \& Holland, 2006, p. 10). Pemberdayaan dise- 
but juga sebagai proses dinamis yang melibatkan tindakan seseorang di dalam kehidupan sehari-harinya untuk memperoleh perubahan personal dan sosial (Akey, Marquis, \& Ross, 2000, pp. 419-438). Pemberdayaan guru merupakan upaya agar dapat lebih optimal dalam bekerjasama (collaboration trought people). Hal ini berhubungan dengan menghargai kemamuan tenaga pendidik (staff recognition). Kemampuan memberdayakan staf juga berkaitan dengan pemberian kesempatan kepada tenaga pendidik untuk mengikuti berbagai pendidikan dan pelatihan secara teratur (Mulyasa, 2011, p. 31). Brown (Priansa \& Suwanto, 2011, pp. 182-183) pemberdayaan erat hubungannya dengan profesionalisme yang pada awalnya selalu dimiliki oleh individual. Dari pendapat di atas dapat disimpulkan bahwa pemberdayaan merupakan suatu kegiatan untuk mengelola sumber daya manusia agar lebih baik lagi sehingga dapat meningkatkan kualitas dan profesionalisme dari individu tersebut.

Pengembangan sumber daya manusia adalah proses untuk meningkatkan kemampuan sumber daya manusia dalam membantu tercapainya tujuan organisasi. Kemampuan sumber daya manusia dapat ditingkatkan melalui program-program pelatihanadan pendidik (Bangun, 2012, p. 5). Manajemen pendidik dan tenaga kependidikan adalah aktivitas yang harus dilakukan mulai dari pendidik dan tenaga kependidikan itu masuk ke dalam organisassi pendidikan sampai akhirnya berhenti melalui proses perencanaan SDM, perekrutan, seleksi, penempatan, pemberian kompensasi, penghargaan, pendidikan dan latihan/pengembangan dan pemberhentian. (Tim Dosen Administrasi Pendidikan Universitas Pendidikan Indonesia, 2009, p. 231).

Profesionalisme guru dibangun melalui penguasaan kompetensi-kompetensi yang secara nyata diperlukan dalam menyelesaikan pekerjaan. Echol \& Shadily (Musfah, 2011, p. 27) bependapat bahwa kompetensi adalah kemampuan pengetahuan, perilaku, dan keterampilan yang harus dimiliki guru untuk mencapai tujuan pembelajaran dan pendidikan. Kompetensi diperoleh melalui pendidikan, pelatihan dan belajar mandiri dengan manfaat sumber belajar. Selain kompetensi, seorang guru profesional juga harus memenuhi persyaratan akademis yaitu kesesuaian kualifikasi akademik guru. Menurut Payong (2011, p. 96) kualifikasi akademik adalah pendidikan formal tertinggi yang sudah diikuti oleh peserta sertifikasi yang dibuktian melalui ijazah atau diploma yang dimiliki. Bagi guru yang sudah berkualifikasi S1/D-4 atau di atasnya (S-2/S-3) dibuktikan dengan ijazah S-1/D-4 atau S-2/S-3. Sementara bagi guru yang belum berijazah S1/D-4 sesuai dengan amanat ketentuan Peralihan pasal 66 Perturan Pemerintah No. 74 tentang guru maka kualifikasi akademik yang dimaksud adalah ijazah pendidikan terakhir (SPG/SOG/SMTA, D-1, D2, D-3/sarjana muda). Bukti fisik untuk komponen ini adalah ijazah atau sertifikat diploma. Pada Peraturan Pemerintah Nomor 74 Tahun 2008 tentang Guru pada bab I pasal 1 "kualifikasi akademik adalah ijazah jenjang pendidikan akademik yang harus dimiliki oleh guru sesuai dengan jenis, jenjang, dan satuan pendidikan formal di tempat penugasan". Dengan kata lain guru profesional memiliki kriteria seperti apa yang disebutkan Nurdin $(2008$, p. 23) yang menjelaskan bahwa guru profesional adalah guru yang mampu menerapkan hubungan yang berbentuk multi dimensional. Guru yang demikian adalah guru yang secara internal memenuhi kriteria administratif, akademis, dan kepribadian.

Alba \& Sandberg (2006, p. 394) berpendapat sebagai berikut.

The concept of proffesional development is not clearly delimited. A profession traditionally is defined as being based om systematic, scientific knowledge. Preliminary development of progessional skill has occured largely trought designated higher education programs, with subsequent development taking various form.

Konsep pengembangan profesional tidaklah dengan jelas dibatasi. Suatu profesi digambarkan sebagai dasar pengetahuan sistematis dan pengetahuan ilmiah. 
Pengembangan keterampilan profesional telah dirancang luas melalui programprogram pendidikan lebih tinggi dengan berbagai bentuk pengembangan.

Murphy \& Calway (2008, p. 434) menyatakan:

Professional associations should encourage self-actualisationn professional development where professionals grow beyond a sufficiency and competence level and become 'learning leaders' of their profession and organisations. Real growth in knowledge combined with the ability to apply that knowledge is vital to the future of professional standards.

Asosiasi profesional harus mendorong aktualisasi diri pengembangan profesional di mana profesional tumbuh melampaui kecukupan dan tingkat kompetensi dan menjadi pemimpin pembelajaran dari profesi dan organisasi mereka. Pertumbuhan riil dalam pengetahuan dikombinasikan dengan kemampuan untuk menerapkan pengetahuan yang sangat penting untuk masa depan standar profesional.

Pengembangan keprofesian guru merupakan proses atau aktivitas yang didesain untuk meningkatkan dan memperluas pengetahuan profesional, keterampilan pedagogis, dan sikap guru atau pendidik sehingga guru atau pendidik itu mamapu melaksanakan proses intruksional tersebut (Craft, 2000, p. 9). Senada dengan pendapat itu, Bellanca (2009, p. 2) menambahkan bahwa pengembangan profesional guru merupakan upaya untuk membekali guru dengan pengetahuan dan keterampilan yang dapat mengarahkan guru itu untuk mengubah kualitas praktik pembelajaran yang dilakukan. Pengembangan dan pembinaan guru sebaikanya dilakukan secara terusmenerus dan berkelanjutan, hal ini bertujuan agar guru dapat memaknai dirinya sebagai guru profesional. Apa yang dikembangkan dan dibinakan pada guru merupakan hal yang berkaitan dengan pengetahuan dan apa yang menjadi keterampilannya, sehingga apa yang dia dapatkan pada saat mengikuti pengembangan dan pembinaan dapat bermanfaat bagi keberlangsungan karirnya. Bubb \& Earley (2007, p. 3)
" a definition of CPD might refer to any professional development activities engaged in by teachers which enhance their knowladge and skills and enable them to consider their attitude", yang dapat diartikan bahwa definisi Pengembangan Keprofesian Berkelanjutan (PKB), sebagai terjemahan konsep Continuous Professional Development (CPD), dapat mengacu pada segala aktivitas pengembangan profesional yang diupayakan dalam/oleh diri untuk meningkatkan pengetahuan dan keterampilan mereka, serta memungkinkan mempertimbangkan dalam sikap perilaku dalam menjalankan tugas. Berdasarkan Permennegpan dan Reformasi Birokrasi Nomor 16 Tahun 2009 yang dimaksud dengan pengembangan keprofesian berkelanjutan (PKB) adalah pengembangan kompetensi guru yang dilaksanakan sesuai dengan kebutuhan, bertahap, berkelanjutan untuk meningkatkan profesionalitasnya. PKB merupakan salah satu komponen pada unsur utama yang kegiatannya diberikan angka kredit. PKB mencakup tiga hal yakni pengembangan diri, publikasi ilmiah, dan karya inovatif.

Berdasarkan uraian yang telah disampaikan tersebut, maka penelitian ini bertujuan untuk mendeskripsikan: (1) pemberdayaan pendidik khususnya PKB SMK Negeri Seni di Kabupaten Bantul; (2) hambatan, dan (3) solusi pemberdayaan pendidik khususnya PKB SMK Negeri Seni di Kabupaten Bantul.

\section{Metode Penelitian}

Pendekatan yang digunakan dalam penelitian ini adalah kualitatif dengan jenis penelitian studi kasus. Penelitian ini dilaksanakan pada bulan Oktober 2015 sampai Maret 2016. Tempat yang digunakan dalam penelitian merupakan tiga sekolah di Kabupaten Bantul yaitu SMK Negeri 1 Kasihan, SMK Negeri 2 Kasihan dan SMK Negeri 3 Kasihan.

Sumber data penelitian ini meliputi: Kepala sekolah Sekolah Menengah Kejuruan, yaitu kepala SMK Negeri 1 Kasihan, SMK Negeri 2 Kasihan, SMK Negeri 3 Kasihan yang terlibat langsung dalam pem- 
berdayaan pendidik (kegiatan pengembangan keprofesian berkelanjutan), pendidik (guru) pada sekolah menengah kejuruan yaitu guru SMK Negeri 1 Kasihan, SMK Negeri 2 Kasihan, SMK Negeri 3 Kasihan, keseluruhan terdiri atas 7 orang guru memiliki pangkat dan golongan minimal IV a dan telah melaksanakan kegiatan pengembangan keprofesian berkelanjutan sebagai penunjang kepangkatan yang telah dimiliki.

Data penelitian ini berupa data kualitatif. Teknik pengumpulan data meliputi observasi, wawancara mendalam dan analisis dokumen. Instrumen penelitian berupa pedoman wawancara, lembar observasi dan alat dokumentasi.

Teknik analisis data yang dilakukan dalam penelitian ini mengadopsi teknik analisis Miles \& Huberman (1984, pp. 2123) yang terdiri dari beberapa langkah yaitu meliputi pengumpulan data, reduksi data, penyajian data, dan penarikan kesimpulan.

\section{Hasil Penelitian dan Pembahasan}

Gambaran tentang SMK Negeri 1 Kasihan

SMK Negeri 1 Kasihan atau yang lebih dikenal dengan nama SMKI Yogyakarta, merupakan lembaga pendidikan formal setingkat SLTA yang termasuk dalam kelompok seni dan kriya untuk bidang keahlian seni pertunjukan. Adapun tugas pokoknya adalah menghasilkan lulusan yang memiliki kemampuan dan keterampilan di bidang seni pertunjukan yang memenuhi persyaratan layak seperti diharapkan oleh dunia kerja/dunia usaha dengan dibekali akhlak mulia dan berbudi luhur. Visi: meningkatkan sumber daya untuk menghasilkan tamatan yang mandiri dan profesional dalam bidang seni pertunjukan sesuai dengan program keahlian masing-masing. Misi: meningkatkan kinerja sekolah untuk menghasilkan tamatan yang berkualitas, kreatif di bidang seni pertunjukan guna memenuhi kebutuhan tenaga kerja seni pertunjukan di era globalisasi.

Gambaran tentang SMK Negeri 2 Kasihan

SMK Negeri 2 Kasihan (Sekolah Menengah Musik) didirikan atas inisiatif ma- syarakat musik dan budayawan yang ada di Indonesia (khususnya pemusik Kraton Yogyakarta). Visi: menjadi sekolah unggul dalam bidang seni musik klasik yang berwawasan lokal yang berdasarkan keimanan dan ketaqwaan. Misi: (a) Mengembangkan sumber daya secara optimal dalam menghadapi kompetensi global; (b) melaksanakan pendekatan pembelajaran berbasis saintifik; (c) mengembangkan sarana dan prasarana sesuai dengan pengembangan IPTEK; (d) mengintegrasikan kearifan lokal dalam pembelajaran; (e) menanamkan nilai-nilai karakter bangsa kepada semua warga sekolah; (f) mengintegrasikan unsurunsur religi dalam semua kegiatan sekolah.

Gambaran tentang SMK Negeri 3 Kasihan

Pada 1977 berganti nama menjadi Sekolah Menengah Seni Rupa (SMSR) Yogyakarta. Nama inilah yang terasa akrab di kalangan masyarakat yang mempunyai hubungan emosional dengan sekolah seni rupa. Pada tahun 1997 secara nasional semua pendidikan Menengah Kejuruan berganti nama menjadi SMK. Karena berada di Kecamatan Kasihan maka SMSR berubah menjadi SMK Negeri 3 Kasihan Bantul.Visi: Terdepan dalam mutu. Misi: (a) Menciptakan tamatan yang berkarakter, bertaqwa kepada Tuhan Yang Maha Esa dan berakhlak mulia; (b) memberikan pelayanan terbaik kepada siswa, orang tua siswa, DU/DI dan masyarakat; (c) melaksanakan pembelajaran secara optimal dan inovatif; (d) meningkatkan kinerja yang efisien dan produktif; (e) menciptakan lingkungan belajar yang kondusif dan nyaman; (f) memperluas hubungan kerja sama dengan DU/ DI dan instansi terkait; (g) menerapkan Sistem Manajemen ISO 9001: 2008 untuk kepuasan pelanggan.

Kondisi Profesionalisme Guru di SMK Negeri Seni Kabupaten Bantul

Penelitian menunjukan bahwa kriteria guru profesional di SMK Negeri Seni Kabupaten Bantul berdasarkan wawancara adalah mempunyai tugas dan tanggung jawab sebagai seorang guru berupa mengajar dan mendidik, mau dan mampu me- 
ningkatkan kualitas dirinya, memiliki sertifikasi profesi, dan memiliki standar kompetensi yang mencakup kompetensi pedagogik, kompetensi kepribadian, kompetensi profesional, dan kompetensi sosial. Hasil wawancara juga menunjukan bahwa kesesuaian kualifikasi akademik guru di SMK Negeri 1 Kasihan terdapat yang sudah sesuai meskipun terdapat juga yang belum sesuai. Kesesuaian kualifikasi akademik guru di SMK Negeri 2 Kasihan diketahui bahwa semua guru dinyatakan memenuhi persyaratan sesuai dengan kualifikasi akademik D-4 atau S-1. Kesesuaian kualifikasi akademik guru di SMK Negeri 3 Kasihan diketahui bahwa guru di sekolah ini memilki kualifikasi akademik yang sudah sesuai.

Tabel 1. Kualifikasi pendidikan guru di SMK Negeri Seni Kabupaten

Bantul

\begin{tabular}{cccc}
\hline $\begin{array}{c}\text { Kualifikasi } \\
\text { pendidikan }\end{array}$ & $\begin{array}{c}\text { SMK N 1 } \\
\text { Kasihan } \\
(\%)\end{array}$ & $\begin{array}{c}\text { SMK N 2 } \\
\text { Kasihan } \\
(\%)\end{array}$ & $\begin{array}{c}\text { SMK N 3 } \\
\text { Kasihan } \\
(\%)\end{array}$ \\
\hline D3 & $3,1 \%$ & $4,5 \%$ & $1,6 \%$ \\
S1 & $85,8 \%$ & $88,7 \%$ & $93,7 \%$ \\
S2 & $11,1 \%$ & $6,8 \%$ & $4,7 \%$ \\
\hline Jumlah & $100 \%$ & $100 \%$ & $100 \%$ \\
\hline
\end{tabular}

Hal ini menunjukan bahwa sebagian guru sudah memiliki kualifikasi yang sesuai dengan pendidikan yang telah ditempuh guru. Bagi guru yang sudah PNS, kualifikasi akademiknya memang sudah sesuai, namun bagi GTT di sekolah ini lebih mementingkan skill dan keahlian dalam mengajar.

Temuan di atas sesuai dengan apa yang diungkapkan oleh Nurdin (2004, p. 23) bahwa guru profesional adalah guru yang mampu menerapkan hubungan yang berbentuk multi dimensional. Guru yang demikian adalah guru yang secara internal memenuhi kriteria administratif, akademis, dan kepribadian. Dari penjelasan ahli tersebut jelas bahwa guru adalah salah satu unsur penting yang harus ada sesudah siswa. Apabila seorang guru tidak punya sikap profesional maka murid yang dididik akan sulit untuk tumbuh dan berkembang de- ngan baik. Hal ini karena guru adalah salah satu tumpuan bagi negara dalam hal pendidikan. Dengan adanya guru yang profesional dan berkualitas maka akan mampu mencetak anak bangsa yang berkualitas pula.

Program Pemberdayaan Guru di SMK Negeri Seni Kabupaten Bantul

Program pemberdayaan SDM (guru) di SMK Negeri 1 Kasihan yaitu sekolah mengadakan program pengembangan SDM (guru) dengan cara terus mengembangkan guru. Salah satu bentuk pemberdayaan tersebut dilakukan dengan adanya ujian kompetensi pagelaran yang dilakukan pada setiap tahun yang berlaku pada kelas tiga. Pada program pengembangan di SMK Negeri 1 Kasihan ini guru dituntut untuk mengembangkan kemampuan dan kreativitas yang dimiliki oleh guru. SMK Negeri $2 \mathrm{Ka}$ sihan menyelenggarakan berbagai macam program pengembangan juga sudah dilaksanakan oleh setiap sekolah seperti workshop dengan mendatangkan pakar-pakar ahli, seminar, penciptaan karya inovatif lainnya, dan berbagai macam pengembangan lainnya. Berdasarkan hasil wawancara dapat ditarik kesimpulan bahwa program pengembangan SDM (guru) di SMK Negeri 3 Kasihan dilakukan dengan cara pemberian tugas, wewenang dan tanggung jawab kepada guru sesuai dengan bidang ilmunya, sesuai dengan job descriptionnya.

Pemberdayaan pendidik merupakan kegiatan dalam manajemen pendidik dan tenaga kependidikan yang wajib ada dalam sebuah instansi atau lembaga. Hal tersebut sejalan dengan apa yang dikemukakan oleh Brown (Priansa \& Suwanto, 2011, pp. 182-183) pemberdayaan erat hubungannya dengan profesionalisme yang pada awalnya selalu dimiliki oleh individual. Pemberdayaan merupakan suatu kegiatan untuk mengelola sumber daya manusia agar lebih baik lagi sehingga dapat meningkatkan kualitas dan profesionalisme dari individu tersebut. Berdasarkan penjelasan ahli di atas dapat dijelaskan bahwa pada dasarnya setiap sekolah seni baik SMK Negeri 1, SMK Negeri 2, dan SMK Negeri 3 Kasihan 
terdapat program pemberdayaan guru dalam bentuk pengembangan guru meskipun bentuk program pengembangannya berbeda-beda dengan tujuan yang sama.

Pelaksanaan Program Pengembangan Keprofesian Berkelanjutan Guru di SMK Negeri Seni Kabupaten Bantul

Berikut adalah gambaran pelaksanaan pengembangan keprofesian berkelanjutan guru di SMK N Seni Kabupaten Bantul. Kegiatan PKB tersebut mencakup kegiatan perenecanaan, pelaksanaan/implementasi dan monitoring atau evaluasi. Berdasarkan hasil wawancara dapat ditarik kesimpulan bahwa dalam pelaksanaan program PKB guru di SMK N 1 Kasihan, SMK N 2 Kasihan dan SMK N Kasihan, masing-masing sekolah tersebut meiliki perencanaan seperti pada tahap awal kepala sekolah membantu memotivasi guru dan mensosialisasikan lebih lanjut mengenai pentingnya kegiatan $\mathrm{PKB}$, menekankan pada semua guru bahwa ini merupakan hal yang wajib diikuti. Kemudian guru dalam ketugasan administratifnya memang sudah ditugaskan untuk menuliskan apa yang akan dilakukan selama satu tahun ke dapan dalam SKP. Dari SKP tersebut dapat diketahui perencanaan kegiatan PKB yang akan dilaksanakan.

Hasil wawancara dan observasi menunjukan bahwa pelaksanaan program PKB guru di SMK N Seni di Kabupaten Bantul ini sudah terlaksana, namun masih belum sepenuhnya. Kepala sekolah masih harus memotivasi dan men-support guru dalam hal pelaksanaan kegiatan PKB, ini dimaksudkan agar guru terus termotivasi untuk melakukan kegiatan PKB tersebut apalagi dalam hal publikasi ilmiah. Di samping itu dalam pelaksanaan kegiatan PKB di SMK Negeri 1 Kasihan dibuat dengan sistem penjenjangan dan rolling, hal ini dimaksudkan dalam hal penciptaan karya seni diharapkan guru dapat menciptakan sebuah karya semua. Di SMK Negeri 2 Kasihan Bantul pelaksanaan kegiatan PKB dilakukan oleh Kepala Sekolah dengan cara ikut serta melakukan penulisan tindakan kelas, membuat karya tulis dan lain sebagainya.
Hal ini dimaksudkan supaya guru ikut termotivasi terhadap contoh yang sudah dilakukan oleh kepala sekolah. Faktanya, adanya pemberian contoh nyata tersebut dalam pelaksanaannya banyak guru yang termotivasi dan memulai melakukan penulisan tindakan kelas, karya ilmiah, seminar, workshop dan lain sebagainya.

Pelaksanaan kegiatan PKB guru di SMK Negeri 3 Kasihan dilakukan oleh pihak sekolah dengan cara mengikutsertakan guru ke dalam berbagai kegiatan salah satunya adalah melalui program penulisan karya ilmiah yang diadakan sekolah bekerja sama dengan pihak Universitas $\mathrm{Ne}$ geri Yogyakarta. Meskipun dari 20 peserta yang ikut, hanya $40 \%$ saja yang sudah melakukan penelitian dan dipresentasikan. Sedangkan, sisanya masih belum memulai karena masalah waktu dan kurangnya rasa percaya diri. Jadi pada SMK N 3 ini dalam pelaksanaan kegiatan PKB melakukan kerja sama dengan instansi terkait supaya kegiatan dapat terlaksana dengan baik dan terarah. Sedangkan untuk kegiatan evaluasi, di SMK N 1, SMK N 2, dan SMK N 3 Kasihan tidak ada evaluasi khusus dalam pelaksanaan program PKB tersebut. Hal tersebut dikarenakan pelaksanaan program PKB termasuk dalam penilaian kinerja guru yang sudah terprogram.

Temuan di atas menunjukan bahwa dalam pelaksanaan kegiatan pengembangan keprofesian berkelanjutan mengacu pada fungsi-fungsi manajemen. Seperti apa yang diungkapkan Terry (Usman, 2013, p. 58) yang menyebutkan bahwa fungsi-fungsi manajemen meliputi perencanaan (planning), pengorganisasian (organizing), pelaksanaan (actuating) dan pengawasan (controling). Setiap kompenen fungsi manajemen penting dalam implementasi kegiatan PKB untuk mencapai tujuan kegiatan yang telah ditentukan. Perlu dirumuskan secara matang untuk pelaksanaannya, karena pelaksanaan merupakan tahap awal yang dilakukan dan sebagai landasan fungsi manajemen, kemudian pengorganisasian, pelaksanaan dan pengawasan juga harus menjadi perhatian dalam suatu kegiatan. 
Sehingga, apa yang menjadi tujuan dapat tercapai dengan pengelolaan yang baik.

Pelaksanaan Kegiatan PKB yang terkait dengan Pengembangan Diri, Publikasi Ilmiah dan Karya inovatif

Kegiatan program PKB yang berkaitan dengan pengembangan diri di SMK N 1 Kasihan dilakukan dengan cara masingmasing guru mengikuti seminar, workshop, membuat rancangan pembelajaran seperti RPP, modul, dan bahan ajar lainnya. Berdasarkan hasil wawancara di atas dapat disimpulkan bahwa kegiatan program PKB yang berkaitan dengan pengembangan diri di SMK Negeri 2 Kasihan terbilang masih jarang dilakukan. Sebab kegiatan seperti halnya seminar, workshop, diklat yang memang khusus berkaitan dengan seni murni memang penyelenggaraannya jarang ada. Namun bentuk-bentuk program pengembangan diri yang sudah dilakukan di SMK N 2 Kasihan Bantul ini diantaranya adalah guru ikut serta dalam kegiatan MGMP, membuat modul atau diktat, terus buku pedoman guru, menyusun program semester, program tahunan, menyusun RPP, melaksanakan proses pembelajaran. Berdasarkan hasil wawancara di atas dapat disimpulkan bahwa kegiatan program PKB yang berkaitan dengan pengembangan diri di SMK N 3 Kasihan sudah bejalan cukup baik, hal ini dikarenakan pihak sekolah sudah membuat perencanaan kegiatan program PKB yang berkaitan dengan pengembangan diri yang dilakukan dengan bekerja sama dengan pakar atau ahli dari instansi terkait. Misalnya dalam hal workshop atu pelatihan, maupun seminar. Guru-guru di sekolah ini juga sering mengikuti diklat fungsional untuk bidang tertentu.

Hasil wawancara dan observasi menunjukan bahwa kegiatan program PKB yang berkaitan dengan publikasi ilmiah di SMK N Seni sudah beberapa guru yang menjalankan program tersebut. Kegiatan publikasi ilmiah ini memang belum berjalan dengan baik sebab banyak guru yang kurang memberanikan dirinya untuk menulis, seperti melakukan penulisan karya ilmiah, melakukan penelitian tindakan ke- las, membuat jurnal ilmiah dan lain sebagainya. Hal ini juga diakui guru dikarenakan minimnya motivasi guru untuk menulis dan karena kurang percaya dirinya guru sehingga kegiatan publikasi ilmiah kurang diminati. Sedangkan, kegiatan program PKB yang berkaitan dengan karya inovatif di SMK N Seni Kabupaten Bantul lebih banyak dilakukan guru. Hal ini dikarenakan karena ketiga sekolah merupakan sekolah seni. Dan bagi guru produktif membuat penciptaan karya seni merupakan hal yang memang sering mereka lakukan. Bagi guru produktif di sekolah seni ini kegiatan program PKB yang berkaitan dengan karya inovatif adalah dengan penciptaankarya seni yang dipentaskan kemudian diportofoliokan. Kemudian pembuatan media pembelajaran yang inofatif juga sudah dilaksanakan oleh beberapa guru.

Di SMK Negeri 1 Kasihan kegiatan program PKB yang berkaitan dengan karya inovatif dilakukan dengan cara program pertunjukan seni dengan ide-ide kreatif dari guru bekerjasama dengan siswa. Kegiatan program PKB yang berkaitan dengan karya inovatif di SMK N 2 Kasihan dilakukan dengan cara penciptaan seni dengan mengaransemen sebuah lagu yang dipertunjukan dan diportofoliokan. Kegiatan program PKB yang berkaitan dengan karya inovatif di SMK Negeri 3 Kasihan dilakukan dengan cara membuat karya monumental sesuai dengan bidangnya yang kemudian dipamerkan dalam bentuk pameran seni rupa dan diportofoliokan. Berdasarkan hasil pengamatan peneliti kegiatan program PKB yang berkaitan dengan karya inovatif di SMK N Seni Kabupaten Bantul merupakan kegiatan pada program PKB yang paling banyak dilaksanakan oleh guru. Hal ini mengingat, kecenderungan guru menciptakan karya seni yang bersifat praktik lebih mudah dilakukan dan dikuasai oleh guru seni dibandingkan dengan kegiatan karya inovatif dan publikasi ilmiah.

PKB merupakan pengembangan keprofesian berkelanjutan yang dilaksanakan sesuai dengan kebutuhan guru untuk mencapai standar kompetensi profesi atau meningkatkan kompetensinya di atas standar 
kompetensi profesinya yang sekaligus berimplikasi kepada perolehan angka kredit untuk kenaikan pangkat/jabatan fungsional guru. Hasil penelitian di SMK Negeri Seni Kabupaten Bantul terkait dengan pelaksanan kegiatan PKB sesuai dengan apa yang disebutkan Kemendiknas (2011, pp. 12-16) yang menyatakan bahwa PKB mencakup tiga hal; yakni pengembangan diri, publikasi ilmiah, dan karya inovatif.

Pengembangan diri adalah upayaupaya untuk meningkatkan profesionalisme diri agar memiliki kompetensi yang sesuai dengan peraturan perundang-undangan agar mampu melaksanakan tugas pokok dan kewajibannya dalam pembelajaran/ pembimbingan termasuk pelaksanaan tugas-tugas tambahan yang relevan dengan fungsi sekolah/madrasah. Kegiatan pengembangan diri terdiri dari diklat fungsional dan kegiatan kolektif guru untuk mencapai dan/atau meningkatkan kompetensi profesi guru yang mencakup: kompetensi pedagogis, kepribadian, sosial, dan profesional. Publikasi ilmiah adalah karya tulis ilmiah yang telah dipublikasikan kepada masyarakat sebagai bentuk kontribusi guru terhadap peningkatan kualitas proses pembelajaran di sekolah dan pengembangan dunia pendidikan secara umum. Publikasi ilmiah meliputi: (1) presentasi pada forum ilmiah, sebagai pemrasaran/ narasumber pada seminar, lokakarya ilmiah, koloqium atau diskusi ilmiah; (2) publikasi ilmiah hasil penelitian atau gagasan inovatif pada bidang pendidikan formal; (3) publikasi buku teks pelajaran, buku pengayaan atau pedoman guru. Karya inovatif adalah karya yang bersifat pengembangan, modifikasi atau penemuan baru sebagai bentuk kontribusi guru terhadap peningkatan kualitas proses pembelajaran di sekolah dan pengembangan dunia pendidikan, sains/teknologi, dan seni. Komponen PKB yang meliputi pengembangan diri, publikasi ilmiah dan karya inovatif. Ketiganya sudah dilaksanakan di SMK Negeri Seni, meskipun dalam pelaksanaannya belum optimal.
Manfaat Kegiatan Pengembangan Keprofesian Berkelanjutan

Hasil wawancara dan observasi menunjukan bahwa manfaat pengembangan keprofesian berkelanjutan yang terstruktur, sistematik dan memenuhi kebutuhan peningkatan keprofesian guru adalah sebagai berikut: (1) guru dapat memenuhi standar dan mengembangkan kompetensinya sehingga mampu melaksanakan tugas-tugas utamanya secara efektif sesuai dengan kebutuhan belajar peserta didik untuk menghadapi kehidupan di masa datang; (2) mampu memberikan layanan pendidikan yang berkualitas kepada peserta didik; (3) memberikan jaminan tentang layanan pendidikan yang berkualitas dan professional; (4) meningkatkan kompetensi guru untuk mencapai standar kompetensi yang ditetapkan dalam peraturan perundangan yang berlaku; (5) memutakhirkan kompetensi guru untuk memenuhi kebutuhan guru dalam perkembangan ilmu pengetahuan, teknologi dan seni untuk memfasilitasi proses pembelajaran peserta didik; (6) meningkatkan komitmen guru dalam melaksanakan tugas pokok dan fungsinya sebagai tenaga professional; (7) menumbuhkan rasa cinta dan bangga sebagai penyandang profesi guru; (8) meningkatkan citra, harkat, dan martabat profesi guru di masyarakat; (9) menunjang pengembangan karir guru. Manfaat yang dirasakan oleh guru dalam kegiatan PKB mengacu pada tujuan PKB yang dikemukakan Brown, Lawrence, \& Robinson (2005, pp. 557-594) menyatakan bahwa tujuan PKB adalah untuk menjamin pengembangan profesional menjadi bermakna dan mengarah kepada kebaruan pengetahuan, keterampilan, dan berbagai praktik yang memungkinkan peningkatan layanan kepada peserta didik, para guru vokasi (termasuk kepala sekolah dan pengawas) perlu mandiri atau mengarahkan diri sendiri dalam melaksanakan pembelajaran dan memikul tanggungjawab untuk menyelaraskan berbagai kesempatan dengan berbagai kebutuhan pembelajaran. 
Faktor Pendukung dan Penghambat Kegiatan PKB

Bentuk dukungan sekolah diberikan melalui kesempatan seluas-luasnya. Artinya sekolah tidak membatasi ruang gerak guru dalam mengembangkan dirinya selama masih bersifat positif dan rasional. Selain itu sekolah juga memberikan dukungan dalam bentuk motivasi kepada setiap guru yang dirasa belum mempunyai kemauan dan kemampuan dalam mengembangkan diri. Salah satunya dengan cara menyediakan fasilitas kepada guru supaya mau mengikuti kegiatan seminar, workshop, diklat ataupun kegiatan lain yang terkait peningkatan profesionalisme guru. Disamping itu dari segi sarana dan prasarana sekolah juga tersedia memadai, sekolah membantu guru dalam kelengkapan administrasi yang diperlukan seperti pemberian surat pengantar maupun surat ijin lainnya yang diperlukan dalam mengikuti berbagai kegiatan. Faktor penghambat dalam pelaksanaan pengembangan keprofesian berkelanjutan (PKB) diantaranya adalah masalah waktu, kurangnya rasa percaya diri, beban pekerjaan yang tinggi dan bagi guru yang kurang tanggap dengan perkembangan teknologi sehingga hal tersebut dianggap sesuatu hal yang membatasi guru dalam berkarya.

Pelaksanaan Kegiatan PKB yang Belum Optimal

Hasil penelitian menunjukan bahwa mayoritas seluruh guru yang menjadi informan dalam penelitian ini paham tentang maksud dan tujuan diadakannya PKB. Program pengembangan keprofesian berkelanjutan adalah program pemerintah yang dicanangkan untuk meningkatkan standar guru dan kenaikan pangkat guru yang ditunjukkan dengan cara membuat karya tulis ilmiah, penelitian tindakan kelas kemudian dengan mengikuti workshop, diklat, seminar sebagai sarana pengembangan diri, dan juga membuat teknologi tepat guna ataupun penciptaan karya seni. Akan tetapi meskipun para guru paham akan program PKB tersebut namun ter- dapat beberapa guru yang merasa belum mampu melaksanakan program tersebut dengan baik dan sesuai anjuran pemerintah. Hal ini dikarenakan keterbatasan waktu guru dan beban pekerjaan yang tinggi membuat guru terkadang kewalahan dalam mengikuti program yang dicanangkan.

Hasil wawancara guru juga menunjukkan bahwa program kegiatan pengembangan keprofesian berkelanjutan guru yang paling banyak diikuti gurudi SMK Negeri 1 Kasihan lebih banyak melakukan karya inovatif. Program kegiatan pengembangan keprofesian berkelanjutan guru yang paling banyak diikuti guru di SMK Negeri 2 Kasihan adalah pengembangan diri dan karya inovatif. Program kegiatan pengembangan keprofesian berkelanjutan guru yang paling banyak diikuti guru di SMK Negeri 3 Kasihan adalah pengembangan diri serta karya inovatif. Guru memilih karya inovatif karena pada program ini merupakan program yang paling sering dilaksanakan oleh guru pada saat pembelajaran berlangsung sehingga memudahkan guru dalam melaksanakan program PKB.

Temuan di atas menunjukan bahwa pelaksanaan PKB belum optimal, sebab idealnya dalam pelaksanaan $\mathrm{PKB}$, ketiga komponen kegiatan PKB harus terlaksanan seimbang. Hal ini sesuai dengan amanat Permennegpan dan Reformasi Birokrasi Nomor 16 Tahun 2009 yang dimaksud dengan pengembangan keprofesian berkelanjutan (PKB) adalah pengembangan kompetensi guru yang dilaksanakan sesuai dengan kebutuhan, bertahap, berkelanjutan untuk meningkatkan profesionalitasnya. PKB merupakan salah satu komponen pada unsur utama yang kegiatannya diberikan angka kredit. Sedangkan, unsur utama yang lain, sebagaimana dijelaskan pada bab $\mathrm{V}$ pasal 11, adalah: (a) pendidikan; (b) pembelajaran/bimbingan dan (c) penunjang. Pelaksanaan PKB juga harus mengacu pada kebutuhan guru yang berkaitan dengan seberapa angka kredit yang dibutuhkan untuk memenuhi persyaratan kenaikan pangkat dan jabatan kariernya. Rangkaian kegitan PKB harus memenuhi indikator penilaian PKB dan dapat menghasil- 
kan sejumlah angka kredit yang dibutuhkan guru.

Upaya yang Dilakukan untuk Mengatasi Kendala PKB

Hasil penelitian menjelaskan bahwa upaya-upaya yang dilakukan kepala sekolah dalam mengatasi hambatan dalam pelaksanaan pengembangan keprofesian berkelanjutan dapat dilakukan dengan cara pemberian motivasi, mengikuti kegiatankegiatan seperti seminar, workshop, diklat, mau dan memiliki niat untuk mengembangkan diri, tidak menutup diri dengan teknologi, dan tidak malu bertanya pada rekan maupun lingkungan apabila tidak mengetahui tentang program tersebut.

Upaya untuk mengatasi hambatan dari segi waktu, maka guru dituntut untuk mampu memanajemen waktu yang dipunya dengan baik. Hal ini dimaksudkan supaya guru tidak hanya menghabiskan waktu untuk kegiatan belajar mengajar, akan tetapi guru juga dituntut untu menyediakan waktu dalam rangka mengembangkan dirinya.

Upaya untuk mengatasi hambatan karena faktor kurangnya rasa percaya diri, maka guru dituntut untuk berani akui diri. Artinya, apabila guru belum tahu dan belum mampu dalam melaksanakan PKB tersebut guru seharusnya tidak segan bertanya dan mencari tahu dari berbagai sumber. Hal ini menjadi penting karena, rasa kurang percaya diri secara tidak langsung dapat membatasi ruang gerak kita untuk maju dan berkembang dalam menyerap segala sumber pengetahuan. Selain itu, dalam meningkatkan kepercayaan diri guru dapat mengikuti kegiatan-kegiatan seperti seminar, workshop, diklat, mau dan memiliki niat untuk mengembangkan diri, tidak menutup diri dengan teknologi, dan tidak malu bertanya pada rekan maupun lingkungan apabila tidak mengetahui tentang program tersebut. Upaya untuk mengatasi hambatan bagi guru-guru yang kurang tanggap dengan perkembangan teknologi maka upaya yang dapat dilakukan pihak sekolah yaitu dengan cara menyediakan sebuah wadah pelatihan-pelatihan untuk meng- upgrade kemampuan tenaga pendidik sesuai dengan kebutuhan dan kemampuannya.

\section{Simpulan}

Kondisi profesionalisme guru di SMK Negeri Seni ditunjukan dengan kualifikasi akademik guru yang sebagian besar sudah sesuai dan memenuhi kriteria guru professional. Program pemberdayaan guru di SMK N Seni Kabupaten Bantul yaitu dengan cara terus mengembangkan guru melalui pengembangan sumber daya manusia. Pelaksanaan Program Pengembangan Keprofesian Berkelanjutan Guru SMK Seni di Kabupaten Bantul meliputi. Pertama, perencanaan yang dilakukan oleh SMK Negeri Seni Kabupaten Bantul dengan cara guru menuliskan apa yang akan dilaksanakan dalam satu tahun ke depan dalam SKP. Kedua, pelaksanaan program PKB guru di SMK Negeri Seni di Kabupaten Bantul ini sudah terlaksana. Ketiga, evaluasi program pengembangan keprofesian berkelanjutan guru dalam rangka meningkatkan profesionalisme di SMK Negeri Seni di Kabupaten Bantul tidak ada evaluasi khusus dalam pelaksanaan program PKB tersebut. Hal tersebut dikarenakan pelaksanaan program PKB termasuk dalam penilaian kinerja guru yang sudah terprogram.

Kegiatan program PKB yang berkaitan dengan pengembangan diri di SMK Negeri Seni di kabupaten Bantul dilakukan dengan cara masing-masing guru mengikuti seminar, workshop, membuat rancangan pembelajaran seperti RPP, modul, dan bahan ajar lainnya. Kegiatan program PKB yang berkaitan dengan publikasi ilmiah di SMK Negeri Seni sudah beberapa guru yang menjalankan program tersebut. Kegiatan program PKB yang berkaitan dengan karya inovatif di SMK Negeri Seni Kabupaten Bantul lebih banyak dilaksanakan. Hal ini dikarenakan karena ketiga sekolah merupakan sekolah seni. Bagi guru produktif membuat penciptaan karya seni merupakan hal yang memang sering mereka lakukan. 
Manfaat dari pengembangan keprofesian berkelanjutan bagi guru adalah guru dapat memenuhi standar dan mengembangkan kompetensinya serta mampu memberikan layanan pendidikan yang berkualitas kepada peserta didik. Faktor pendukung program pengembangan keprofesian berkelanjutan antara lain dukungan sekolah terhadap pengembangan keprofesian berkelanjutan guru dalam rangka meningkatkan profesionalisme guru dilakukan dengan cara memberikan kesempatan seluas-luasnya kepada guru untuk mengikuti pengembangan profesi guru. Sedangkan faktor hambatan dalam pelaksanaan PKB guru adalah masalah waktu, kurangnya rasa percaya diri, beban pekerjaan yang tinggi dan bagi guru-guru yang kurang tanggap dengan perkembangan teknologi sehingga hal tersebut dianggap sesuatu hal yang membatasi guru dalam berkarya.

Pelaksanaan PKB yang belum optimal disebabkan karena PKB guru yang lebih banyak diikuti adalah kegiatan karya inovatif, karena ketiga sekolah tersebut merupakan sekolah menengah kejuruan seni, sehingga banyak guru produktif yang lebih sering membuat penciptaan karya seni. Padahal idealnya guru harus mampu melaksankan ketiga komponen kegiatan PKB tersebut. Upaya yang dilakukan dalam mengatasi kendala/hambatan kegiatan PKB diantaranya guru dituntut untuk mampu memanajemen waktu yang dipunya dengan baik. Serta berani untuk akui diri. Bagi guru-guru yang kurang tanggap dengan perkembangan teknologi maka upaya yang dapat dilakukan pihak sekolah yaitu dengan cara menyediakan sebuah wadah pelatihan-pelatihan untuk mengupgrade kemampuan masing-masing tenaga pendidik sesuai dengan kebutuhan dan kemampuannya.

Berdasarkan hasil penelitian ini dapat diajukan beberapa saran sebagai berikut: (1) Guru dapat melibatkan diri dalam berbagai kegiatan pengembangan keprofesian berkelanjutan sehingga dapat meningkatkan kualitas kerja guru, (2) Guru mampu menyediakan waktu dalam kegiatan pengembangan keprofesian berke- lanjutan sehingga akan meningkatkan pengalaman, dan wawasannya, (3) Kepala sekolah hendaknya melakukan evaluasi secara berkala terhadap program pengembangan keprofesian berkelanjutan, (4) Sekolah hendaknya memberikan reward bagi guru yang mampu mengembangkan diri dalam berbagai kegiatan, (5) Sekolah hendaknya memberikan sanksi bagi guru yang tidak bersedia mengembangkan diri, (6) Sekolah menyediakan sarana pelatihan bagi guru-guru yang kurang paham akan penggunaan teknologi saat ini, (7) Bagi peneliti lain hendaknya melakukan penelitian dengan menggunakan pendekatan yang berbeda dan dengan objek yang berbeda pula, sehingga hasil dari penelitian akan dapat lebih menyempurnakan hasil penelitian ini.

\section{Daftar Pustaka}

Akey, T. M., Marquis, J. G., \& Ross, M. E. (2000). Validation of score on the psychological empowerment scale, a measure of empowerment for parent of children with a disability. Education and Psychological Meansurement, 60(3), 419-438.

Alba, G. D., \& Sandberg, J. (2006). Unveiling professional development: A critical review of stage models. Review of educational research (RER). Journal. America. DC A Quarterly Publication of The American Educational Research Association, 76(3), 384.

Retrieved from https://www.academia.edu/1315646 9/Unveiling_Professional_Developme nt_A_Critical_Review_of_Stage_Mode ls

Aslop, R., Bertelson, M. F., \& Holland, J. (2006). Empowerment in practice: from analysis to implementation. Washington DC: IBRD The Word Bank.

Bangun, W. (2012). Manajemen sumber daya manusia. Jakarta: Erlangga.

Bellanca, R. A. (2009). Designing professional development for change. California: Corwin Press. 
Brown, G., Lawrence, T. B., \& Robinson, S. L. (2005). Territorially in organizations. Academy of Management Review, 30(3), 577-594.

Bubb, S., \& Earley, P. (2007). Leading and managing continuing professional development (2nd ed.). London: Institute of Education, University of London.

Craft, A. (2000). Continuing professional development: A practical guide for teachers and school (2nd ed.). London: Rautledge Falmer.

Engkoswara, \& Komariah, A. (2010). Administrasi pendidikan. Bandung: $\mathrm{CV}$ Alfabeta.

Kemendiknas. (2011). Pedoman pengelolaan pengembangan keprofesian berkelanjutan (PKB) Buku 1. Jakarta: Direktorat Pembinaan Pendidik dan Tenaga Kependidikan.

Mahapatro, B. B. (2010). Human resource managmenet. New Delhi: New Age International Publisher.

Miles, M. B., \& Huberman, A. M. (1984). Qualitative data analysis: A sourcebook of new methods. Thousand Oaks, CA: Sage.

Mulyasa, E. (2011). Manajemen $\mathcal{E}$ kepemimpinan kepala sekolah. Jakarta: Bumi Aksara.

Murphy, G. A., \& Calway, B. A. (2008). Professional development for professionals: beyond sufficiency learning. swinburne University of Technology, Lilydale, Australia. Australian Journal of Adult Learning, 48(3).
Musfah, J. (2011). Peningkatan kompetensi guru melalui pelatihan dan sumber belajar teori dan praktik. Jakarta: Kencana Prenada Media Grup.

Northouse, P. G. (2013). Leadership: theory and practice (6th ed.). California: Sage publications, Inc.

Nurdin, M. (2008). Kiat menjadi guru profesional. Yogyakarta: Ar-ruzz Media.

Payong, M. R. (2011). Sertifikasi profesi guru. Jakarta: Indeks.

Priansa, D. J., \& Suwanto. (2011). Manajemen SDM dalam organisasi publik dan bisnis. Bandung: Alfabeta.

Suprijadi. (2014). PKG/PKB, sebuah idealisme? Buletin Bina Prestasi Dinas Pendidikan Menengah Dan Nonformal Kabupaten Bantul, 34-35.

Tim Dosen Administrasi Pendidikan Universitas Pendidikan Indonesia. (2009). Administrasi pendidikan. Bandung: Alfabeta.

Tim Dosen Administrasi Pendidikan Universitas Pendidikan Indonesia. (2013). Manajemen pendidikan. Bandung: Alfabeta.

Usman, H. (2013). Manajeman: teori, praktik, dan riset pendidikan (4th ed.). Jakarta: PT Bumi Aksara.

Wibowo, A. (2013). Manajemen pendidikan karakter di sekolah (konsep dan praktik implementasi). Yogyakarta: Pustaka Pelajar. 